\title{
Butrus b. Bûlûs el-Bustânî̀nin Son Dönem Osmanlı Dönemi Reform Öncülügü ve Türk Edebiyatına Etkisi
}

\section{Butrus b. Bolus al-Bustani's Last Ottoman Period Reform Leading and Its Influence on Turkish Literature}

\section{Emin Uz}

Dr. Öğr. Üyesi, Afyon Kocatepe Üniversitesi, İslami İlimler Fakültesi, Arap Dili ve Belagatı Anabilim Dalı Assist. Prof, Afyon Kocatepe University, Faculty of Islamic Sciences, Department of Arabic Language and Rhetoric Afyonkarahisar / Turkey

eminuz83@gmail.com.tr | https://orcid.org/0000-0003-3255-7543

Corresponding Author / Sorumlu Yazar

\section{Muhammed Efil}

Öğr. Gör. Dr., Necmettin Erbakan Üniversitesi, Illahiyat Fakültesi, Arap Dili ve Belagatı Anabilim Dalı PhD. Lecturer, Necmettin Erbakan University, Faculty of Theology

Konya, Turkey

muhammed.efil@gmail.com | https://orcid.org/0000-0003-0385-1866

Article Type / Makale Tipi

Research Article / Araştırma Makalesi

DOI: $10.33420 /$ marife.1000110
Article Information / Makale Bilgisi

Received / Geliş Tarihi: 24.09.2021

Accepted / Kabul Tarihi: 29.11.2021

Published / Yayın Tarihi: 30.12.2021

Cite as / Atıf: Uz, Emin- Efil, Muhammed. "Butrus b. Bûlûs el-Bustânî'nin Son Dönem Osmanlı Dönemi Reform Öncülügü ve Türk Edebiyatına Etkisi”. Marife 21/2 (2021): 1247-1265.

https://doi.org/10.33420/marife.1000110.

Plagiarism / Intihal: This article has been reviewed by at least two referees and scanned via a plagiarism software. / Bu makale, en az iki hakem tarafından incelendi ve intihal içermediği teyit edildi.

Copyright / Telif Hakkı: "This article is an open access article distributed under the terms and conditions of the Creative Commons Attribution-NonCommercial-NoDerivatives 4.0 (CC BY-NC-ND 4.0) International License." / "Bu makale Creative Commons Alıntı-GayriTicari-Türetilemez 4.0 (CC BY-NCND 4.0) Uluslar arası Lisansı altında lisanslanmıştır." 


\section{Butrus b. Bûlûs el-Bustânînnin Son Dönem Osmanlı Dönemi Reform Öncülüğü ve Türk Edebiyatına Etkisi}

\section{Özet}

Lübnanlı bir dil bilimci olmasının yanı sıra uluslararası eğitimci kimliği ile de tanınan Butrus b. Bûlûs el-Bustânî, Arap dilinin dünya çapındaki ilmî ve edebî uyanışında önemli payı olan fikir adamlarındandır. Bu nedenle de düșünce, dil ve edebiyattaki etkisi, Lübnan'la sınırlı kalmamış diğer Arap bölgelerine hatta dünyanın birçok bölgesine de ulaşmıştır. el-Bustânî̀nin yaşadı̆̆ı dönemde Suriye bölgesinde Sünni Müslüman çoğunluğa ek olarak birçok gayrimüslim azınlık yașamaktadır. Gayrimüslimler ağırlıklı olarak Ortodoks, Katolik, Mârûnî ve Yahudilerdir. Sünni olmayan dinî gruplar ise Alevî, İsmâilî ve Dürzî gruplardır. Her dinî cemaatin kendi hiyerarşisi ve coğrafi izolasyonu içerisinde belirli bir iç dayanışma ruhu vardır. Bu grupların çoğu, geçmişte dinsel baskılardan korunmak için Suriye'nin tenha dağlık bölgelerine sığındıktan sonra hem birbirlerinden hem de Sünni Müslüman çoğunluktan sosyal ve kültürel olarak izole yaşamaktadırlar. Daha sonraları Mârûnî köylüler, ipek endüstrisinde iș aramak için güneye -Dürzi emirlerin hâkim olduğu-göç etmeye başladılar. Göç edilen bölgelerde Rum, Ortodoks ve Katolik aileler Şuveșfat, Kafr, Şîma ve Şemlân gibi bölgelerde küçük entelektüel merkezler kurmuşlardı. Mârûnî bir aileye mensup olan Butrus, bu bölgelerde ana dili olan Arapça yanında Süryaniceyi de iyi derecede öğrenmiștir. Daha sonra din görevlisi yetiştiren okullardan biri olan Ayn Varaka Medresesi'nde yaklaşık on yıl kadar dil, tarih, mantık, felsefe ve ulûmu'd-dîn dersleri okumuștur. Bu yıllarda özellikle dil alanında kendisini bir hayli geliștirmiş Arapça ve Süryanicenin yanında Ittalyanca ve Latinceyi de dil birikimi içerisine dâhil etmiştir. Sonraki yıllarda öğrenim gördüğü bu okulda müderrislik yapma imkânı da bulmuştur. Bu okulda elde ettiği İngilizce birikiminden haberdar olan İngiliz siyasetçiler, kendisini özellikle bürokratik alanda mütercim olarak kullanmışlardır. Nitekim el-Bustânî, dönemin Mısır valisi İbrahim Paşa ile İngilizler arasında Osmanlı Devleti'nin Lübnan ve Suriye'den çekilmesi konusunda tercümanlık yapmıștır. Mütercimlik yaptığı dönemde Amerikan misyonerlerle dostluk kurmuș ve onların faaliyetlerine katkı sağlamıştır. Nitekim tesis etmiş olduğu el-Cem'iyyetü'l- edebiyyeti'l-ilmiyye isimli kuruluş bünyesinde Amerikan misyonerler de üye olarak yer almaktadır. Bunun yanında Beyrut'ta gerçekleștirilen Kitâb-ı Mukaddes tercümesi çalışmalarında da bilfiil görev yapmıștır. elBustânî, modernleșme mesajını, zamanının potansiyellerini göz önünde bulundurarak olumlu, pratik ve barış̧̧ıl yollarla iletmiştir. Onun hayatı, Suriye vatanseverliği ile Osmanlıcllık arasında bir çizgide yürümenin öyküsüdür. Birincisi her zaman en az ikincisi kadar yüreğine yakındır. Kendisine göre topyekûn olma, bölgesel bir bileșenle değil kültürel bir bileșenle başlamaktadır. Butrus hayatı boyunca dini siyasetten ayırmanin gerekliliğini savundu. Bu yüzden dinî ve sivil otoriteler arasına çok net sınırlar koymaya çalıșmıștır. Kör fanatizmin inanç eksikliğinden ve dini yanlış anlamadan kaynaklandığııı sıkça dillendirmiștir. Bu haykırıșı bazı guruplar nazarında devlet yönetimine muhalif bir tavır gibi algılansa da aksine o, Osmanlı devletinin yanında durmuş ve yönetenlere karşı bir devrim çağrısında bulunmamıștır. Onun çağrısı, Türkler ile Osmanlı İmparatorluğu'nun diğer sakinleri arasında reform, medeniyet ve eșit haklarla sinırlıdır. el-Bustânî, Şubat 1859'da Beyrut'ta, Arap dili ve kültürünün canlandırılması için çağrıda bulunduğu "Arap Edebiyatı Üzerine" isimli konferansında dinleyicilerine, çeșitli ulusların dillerini Araplar arasında yaymakla meșgul olduklarını; Arapların ise "ana dillerine dikkat etmeden yabancı dil ögrenmeye büyük bir eğilim gösterdiğini" söyleyerek bir tehlikeye dikkat çekmiștir. Ona göre dilin öğrenilmesini kolaylaștırmak ve daha arzu edilir kılmak için dil ile birlikte dilbilgisi de "yeniden düzenlenmelidir". Arapların dil mücadelesinin yanında medeniyete katkıları da unutulmamalıdır. İçinde yaşadığı toplumu "eski bilimler ile modern bilimler arasında köprü" olarak niteleyen düşünür, halkını zihinsel tembellik konusunda suçlamış ve onlara sanat ve bilim kitaplarının basımı, süreli yayınların yayınlanması, kütüphanelerin açılmasl, okulların kurulması gibi diriliş̧ ortamları önermiştir. Araștırmanın amaçları doğrultusunda bu başlık altında üç kilit şahsiyetin -Butrus el-Bustânî, Namık Kemal ve Ziya Gökalp- telifatlarına ve faaliyetlerine yönelmek suretiyle hem ideoloji hem de edebi anlamda dönemin fikriyatına lşı tutulmaya çalışlacaktır. Nitekim mezkûr isimlerden el-Bustânî ve Namık Kemal, ıslahat döneminin ilk periyodunda farklı coğrafya ve kültüre ait vatan duygusunun fikri temsilciliğini yapmıs, Ziya Gökalp ise ikinci periyotta milliyetçilik düşüncesini zirveye taşımıștır. Bu isimler doğrudan siyasi bir bağlıliğı olmayan, ancak ögrretileri kendi zamanlarının sosyal ve politik gelişmelerini yansitan önde gelen entelektüeller ve ideologlardır. Nihayetinde, düşünürlerin bu konfigürasyonu ilginçtir. Çünkü Butrus el-Bustânî (Osmanlıcı) ve Ziya Gökalp (Milliyetçi) arasındaki eksik halkayı tamamlayan Namık Kemal 
olmuştur. Tabii ki söz konusu edipler arasında bu marjinalliği ilk ortaya koyan daha önce de belirtildiği gibi Butrus el-Bustânî olmuştur. Bu nedenle çalıșmamızda 19. yüzyıl reformist düşüncenin temellerini atan el-Bustânî bașta olmak üzere Anadolu'daki takipçileri Namık Kemal ve Ziya Gökalp'in telifat ve faaliyetleri ışığında dönemin edebî ve fikrî yapısına ışılk tutulmaya çalışılacaktır.

Anahtar Kelimeler: Arap Dili ve Belagatı, Türk Edebiyatı, Butrus el-Bustânî, Namık Kemal, Ziya Gökalp.

\section{Butrus b. Bûlûs al-Bustânî's Leading of Reform in the Late Ottoman Period and Its Influence on Turkish Literature}

\section{Summary}

In addition to being a Lebanese linguist, Butrus b. Bûlûs al-Bustânî is one of the intellectuals who had an important role in the literary awakening of the Arabic language and science. For this reason, his influence in conception, language, and literature was not limited to Lebanon, but also reached other Arabic countries and even many parts of the world.

During the period of al-Bustani, in addition to the Sunni Muslim majority, many non-Muslim minorities had lived in the Syrian region. Non-Muslims were predominantly Orthodox, Catholic, Maronite, and Jews. Non-Sunni religious groups were Alevites, Ismailis, and Druzes. Each religious community had its hierarchy and a certain spirit of internal solidarity within the area. Most of these groups, after taking shelter in the secluded mountainous regions of Syria to avoid religious pressure, had lived isolated socially and culturally from both each other and the Sunni Muslim majority in the past. In this region, Butrus, who was a member of a Maronite family, learned Syriac very well as well as Arabic, which was his mother tongue. Al-Bustani acted as a translator between Ibrahim Pasha, the governor of Egypt of the day, and the British on the withdrawal of the Ottoman Empire from Lebanon and Syria. American missionaries also took part in the organization he established called alCem'iyyetü'l-ebiyyeti'l-ilmiyye. In addition, he actively worked in the translation of the Bible in Beirut. Al-Bustani conveyed the message of modernization in positive, practical, and peaceful ways, considering the potentials of that time. His life is a story of walking the line between Syrian patriotism and Ottomanism. Throughout his life, Butrus defended the necessity of separating religion from politics. Therefore, he had tried to set very clear boundaries between religious and civil authorities. He expressed that blind fanaticism arises from beliefs and religious misunderstanding. Although this outcry of his was perceived as an opposition to the state administration by some groups but on the contrary, he stood by the Ottoman state and did not call for a revolution against the rulers. His call was limited to reform, civilization, and equal rights between Turks and other inhabitants of the Ottoman Empire.

Al-Bustani, in his conference "On Arab Literature" in February 1859 in Beirut, called for the revival of the Arabic language and culture, and told the audience that they were busy spreading the languages of various nations among the Arabs; He drew attention to danger by saying that Arabs "have a great tendency to learn foreign languages without paying attention to their mother tongue". According to him, grammar should be "reorganized" along with language to make language learning easier and more desirable. The thinker, who described the society he lived in as "a bridge between ancient sciences and modern sciences", accused his people of mental laziness and suggested resurrection initiations such as publishing art and science books, publishing periodicals, opening libraries, and establishing schools.

In line with the purposes of the research, under this heading, we will try to shed light on the ideas of the period, both in terms of ideology and literature, by focusing on the writings and activities of three key figures - Butrus el-Bustânî, Namık Kemal and Ziya Gökalp-. Al-Bustani and Namık Kemal, among the aforementioned names, had been the ideological representer of the sense of homeland belonging to different geography and culture in the first period of the reform period, while Ziya Gökalp in the second period, pushed the nationalism idea over the top. These names are prominent intellectuals and ideologues without a direct political affiliation, but whose doctrines reflect the social and political developments of their time. Finally, this configuration of thinkers is interesting. Because it was Namik Kemal who completed the missing link between Butrus al-Bustani (Ottomanist) and Ziya Gokalp (Nationalist). Of course, as mentioned before, Butrus al-Bustani was the first to reveal this marginality among the aforementioned literati. For this reason, in our study, we will try to shed light on the literary and intellectual structure of the period in the light of the works and activities of especially al- 
Bustani, who laid the foundations of the 19th-century reformist thought and his followers in Anatolia, Namık Kemal, and Ziya Gökalp.

Keywords: Arabic Language and Rhetoric, Turkish Literature, Butrus al-Bustanı, Namık Kemal, Ziya Gökalp.

\section{Giriş}

Lübnanlı bir dil bilimci olmasının yanı sıra uluslararası eğitimci kimliği ile de tanınan Butrus b. Bûlûs el-Bustânî (ö. 1300/1883), Arap dilinin dünya çapındaki ilmî ve edebî uyanıșında önemli payı olan fikir adamlarındandır. Bu nedenle de düşünce, dil ve edebiyattaki etkisi, Lübnan'la sınırlı kalmamış diğer Arap bölgelerine hatta dünyanın birçok bölgesine de ulaşmıştır.

el-Bustânî̀nin yaşadığı dönemde Suriye toplumunun yapısı, en az Osmanlı İmparatorluğu'nunki kadar parçalıdır. Bu bölgede Sünni Müslüman çoğunluğa ek olarak birçok gayrimüslim azınlık yaşamaktadır. Gayrimüslimler ağırlıklı olarak Ortodoks, Katolik, Mârûnî ve Yahudilerdir. Sünni olmayan dinî gruplar ise Alevî, İsmâilî ve Dürzî gruplardır. Her dinî cemaatin kendi hiyerarşisi ve coğrafi izolasyonu içerisinde belirli bir iç dayanışma ruhu vardır. Bu grupların çoğu, geçmişte dinsel baskılardan korunmak için Suriye'nin tenha dağlık bölgelerine sığındıktan sonra hem birbirlerinden hem de Sünni Müslüman çoğunluktan sosyal ve kültürel olarak izole yaşamaktadırlar. ${ }^{1}$ Daha sonraları Mârûnî köylüler, ipek endüstrisinde iş aramak için güneye -Dürzi emirlerin hâkim olduğu- göç etmeye başladılar. Göç edilen bölgelerde Rum, Ortodoks ve Katolik aileler Şuveșfat, Kafr, Şîma ve Şemlân gibi bölgelerde küçük entelektüel merkezler kurmuşlardı. ${ }^{2}$ Mârûnî bir aileye mensup olan Butrus, bu bölgelerde ana dili olan Arapça yanında Süryaniceyi de iyi derecede öğrenmiștir. Daha sonra din görevlisi yetiștiren okullardan biri olan Ayn Varaka Medresesi'nde yaklaşık on yıl kadar dil, tarih, mantık, felsefe ve ulûmü'ddîn dersleri okumuştur. Bu yıllarda özellikle dil alanında kendisini bir hayli geliştirmiş Arapça ve Süryanicenin yanında İtalyanca ve Latinceyi de dil birikimi içerisine dâhil etmiştir. Sonraki yıllarda öğrenim gördügü bu okulda müderrislik yapma imkânı da bulmuștur. ${ }^{3} \mathrm{Bu}$ okulda elde ettiği İngilizce birikiminden haberdar olan İngiliz siyasetçiler, kendisini özellikle bürokratik alanda mütercim olarak kullanmışlardır. Nitekim el-Bustânî, dönemin Mısır valisi İbrahim Paşa ile İngilizler arasında Osmanlı Devleti'nin Lübnan ve Suriye'den çekilmesi konusunda tercümanlık yapmıştır. Mütercimlik yaptığı dönemde Amerikan misyonerlerle dostluk kurmuş ve onların faaliyetlerine katkı sağlamıștır. ${ }^{4}$ Nitekim tesis etmiş olduğu el-

1 Darin Stephanov, "Patriotism in Transition: The Thought of Butrus al-Bustani, Mehmed Said Pasha and Ziya Gokalp”, Butrus Al-Bustani: Spirit of the Age, ed. Beshara Adel (Melbourne: CreateSpace Independent Publishing Platform, 2014), 199.

2 Butrus al-Bustani, The Clarion of Syria: A Patriot's Call against the Civil War of 1860, çev. Jens Hanssen Hicham Safieddine (California: University of California Press, 2019), 23.

3 Butrûs b. Süleymân el-Bustânî, Üdebâ'ü 'l-'Arab fi'l-Câhiliyye ve sadri'l-İslâm (Kahire: Müessesetü Hindî, 2014), 341; Phillippe De Tarrâzî, Târîhu's-sıhâfeti'l-'Arabiyye (Beyrut, 1913), 2/89; Mülhim İbrahim el-Bustânî, Kevserü'n-nüfûs (Lübnan, 1954), 2/89; Yusuf Kazma Huri, Racülün sâbıkun liasrihî: el-mu'allim Butrus el-Bustânî (Beyrut: Bisân li'n-Neșr, 1995), 236 s./5-10.

4 Yûsuf Es'ad Dâgır, Mesâdirü'd-dirâseti'l-edebiyye (Beyrut: el-Menșûrâtü'l-Câmia, 1983), 2/181; Ali 
Cem'iyyetü'l-edebiyyeti'l-ilmiyye isimli kuruluş bünyesinde Amerikan misyonerler de üye olarak yer almaktadır. ${ }^{5}$ Bunun yanında Beyrut'ta gerçekleștirilen Kitâb-ı Mukaddes tercümesi çalıșmalarında da bilfiil görev yapmıștır. ${ }^{6}$

Butrus el-Bustânî, Beyrut’ta yaşadığı dönemde birçok resmî kurum ve kuruluşta görev yapmış ve farklı okullarda eğitmenlik görevlerini üstlenmiştir. Bu görevleri esnasında ilmî alanda da velûd kimliği ile tanınmış ve onlarca telifat ortaya koymuştur.

\section{Eğitim ve Edebiyat Alanındaki Çalışmaları}

1863 yılında Beyrut'ta el-Medresetü'l-Vataniyye'yi (Ulusal Okul) kurmak suretiyle hem ilmî bir ekol oluşturmanın temellerini atıyor hem de söz konusu okulu bölgede yaşayan bütün dinî gruplara açmak suretiyle toprak ve dil temelinde karşılıklı çıkarlar üzerine kurulu bir vizyon oluşturuyordu. el-Bustânî̀nin Ulusal Okulu'nu kurmadaki temel pedagojik hedefleri arasında, ülkesinde birlik tohumlarını besleyebilecek bir ortam sağlamak ve aynı zamanda ülkenin gençleri arasın da bilim ve bilgiyi teşvik etmek vardı. 0 , okulunun gerçekten millî ve dinî bağnazlıktan uzak olmasını, öğrenciler arasında karşılıklı sevgi duygusunu teşvik etmesini istiyordu. "Ülkenin tüm çocukları (ümmet) için kültürel kimliklerini koruyabilen bir eğitim sistemi"7 çağrısında bulundu. Bu nedenle el-Bustânî tarafından savunulan eğitim projesi, toplumun farklı kesimleri arasındaki uyumu güçlendirmeyi amaçladığından misyonlarınkinden farklılık arz etmekteydi.

Butrus hayatı boyunca dini siyasetten ayırmanın gerekliliğini savundu. $\mathrm{Bu}$ yüzden dinî ve sivil otoriteler arasına çok net sınırlar koymaya çalıştı. Kör fanatizmin inanç eksikliğinden ve dini yanlış anlamadan kaynaklandığını sıkça dillendirmiştir. Bu haykırıșı bazı guruplar nazarında devlet yönetimine muhalif bir tavır gibi algılansa da aksine o, Osmanlı devletinin yanında durmuş ve yönetenlere karşı bir devrim çağrısında bulunmamıştır. Onun çağrısı, Türkler ile Osmanlı İmparatorluğu'nun diğer sakinleri arasında reform, medeniyet ve eşit haklarla sınırlıydı. ${ }^{8}$ Osmanlı Türk makamlarının temsilcilerinin okula yaptıkları ziyaretler ve kendisine gönderdikleri mektuplar, okulun inşa edildiği ilkeleri kabul ettiklerinin bir göstergesidir. Nitekim Sultan Abdülaziz, bu okulu kurma başarısından dolayı elBustânî'ye "Mecid Nişanı" vermiş; akabinde bu çabaya destek olarak Osmanlı valileri tarafından sık sık ziyaret edilmiştir. ${ }^{9}$ Nâsîf el-Yâzîcî gibi dönemin önemli mual-

Şakir Ergin, "Bustânî, Butrus b. Bûlus", TDV İslâm Ansiklopedisi (İstanbul: TDV Yayınları, 1992), $6 / 473$.

5 el-Bustânî, Kevserü'n-nüfûs, 345.el-Bustânî, Mülhim İbrahim, Kevserü'n-nüfûs, Lübnan, 1954, s.345.

6 Yûsuf b. İlyân b. Mûsâ Serkîs, Mu'cemü'l-matbû'âti'l-arabiyye ve'l-mu'arrabe (Matbaatü Serkîs, 1928), $1 / 557$.

7 Butrus Abu-Manneh, "The Christians Between Ottomanism and Syrian Nationalism: The Ideas of Butrus Al-Bustani", International Journal of Middle East Studies 11 (1980), 194.

8 Pierre Georges Raffoul, Butrus al-Bustanî Study of his Life, Achievements and Ideas (Sydney: The University of Sydney, 2001), ii. 
limleri de bu okulda ileri seviyede Arapça dersleri vermiştir. Söz konusu eğitim kurumu dışında Lübnan başta olmak üzere birçok ülkede kurulan eğitim ve hayır müesseselerinin üyeliğini yapan müellif, bölgenin kültürel ve ahlaki problemlerini isabetli bir şekilde değerlendiren eğitimci bir yazardır. Bu gayretleri sebebiyle "elmuallim" lakabı ile tanınmıştır. ${ }^{10}$

Ulusal okulunun açılması sadece eğitim değil telif faaliyetlerinin de önünü açmıştır. Zira birçok telif, gazete ve dergi bazında millî amaçlı projeler bu okul bünyesinde kendisi, arkadaşları ve öğrencileri tarafından uygulamaya konulmuştur. Bu dönem, hayatının en verimli yıllarıdır. Çünkü Muhîtu'l-Muhît, Kutru'l-Muhît ve Dâiretü'l-me'ârif gibi eserleri yazma, pek çok konferans verme ve risaleler telif etme faaliyetlerinin çoğu bu dönemde gerçekleşmiştir. Nitekim Butrus, Dâiratü'lme'ârif adlı ansiklopedisinin yedinci cildini hazırladığı esnada vefat etmiștir. Yedinci ve sekizinci cildini oğlu Selim, diğer ciltlerini ise Selim'in oğulları Necip ve Emin tamamlamıştır. İlk modern Arapça sözlük olarak kabul edilen Muhîtu'l-Muhît, müellifin mezkûr ansiklopedisinden sonraki en meşhur eseridir. Sözlügünü yazarken Fîrûzâbâdî'nin meşhur el-Kâmûs'ul-mûhît'inden yararlanmış ve Arapça sözlügün modernizasyonunda başarı sağlamıștır. el-Kâmûs'ul-mûhît'in sıralamasından farklı olarak alfabetik sıralamayı tercih ettiği ${ }^{11}$ Kâmûs'un metninde yaptığı iyileştirmelerle onu modern Arap okurun ihtiyaçlarına en çok cevap veren sözlük haline getirmiştir. ${ }^{12}$ Kutru'l-Muhît adlı sözlüğü ise Muhîtu'l-Muhît'in muhtasarıdır. Gramer alanında kaleme aldığı eserleri Misbâhu't-tâlib ve Miftâhu'l-misbâh șeklinde zikredilebilir. Gramer ve ansiklopedik tür dıșında kaleme almış olduğu Tercümetü'tTevrât (Tevrat Tercümesi), Hutbetü âdâbi'l-'Arab, Târîhu Napolyon, Ravdatü't-tâcir, Keşfüll-hicâb, et-Tuhfetü'l-bustâniyye, Şerhu Dîvâni'l-Mütenebbî, el-Hey'etüllictimâ'iyye, Ta'lîmu'n-nisâ, Sîretü Es'ad eş-Şidyâk gibi tarih, edebiyat, ticaret ve pedagoji alanlarına dair birçok eseri bulunmaktadır. ${ }^{13}$ Üdebâül-Arab ismindeki dil tarihine dair eser de kendisine atfedilmiş olup ${ }^{14}$ araștırmamıza göre bu eser müellifimiz Butrus b. Bûlûs el-Bustânî̀ye değil Butrus b. Süleymân el-Bustânîye aittir. ${ }^{15}$ Süreli yayınlar dizisine gelindiğinde bizzat kendisinin yayınlamış olduğu inançlar arası birliğin gerekliliğini vurgulayan ve ülkede yayınlanan ilk siyasi dergi unvanına sahip Nefîr Sûriye isimli dergi karşımıza çlkmaktadır. ${ }^{16}$ Ayrıca bu dergi Bey-

$\longrightarrow$

English/AlBustani/Al\%20Bustani\%20Biography.pdf

${ }^{10}$ Fu'âd Afrâm Bustânî, el-Mu'allim Butrus el-Bustânî (Beyrut: el-Mektebetü's-Şarkıyye, 1975).

${ }^{11}$ Ahmed Muhtâr Ömer, el-Bahsu'l-luğavî 'Inde'l-'Arab (Kahire: Âlemü'l-Kütüb, 1988), 310.

12 Cüveyde Ma'bûd, Mine'l-kâmûs'il-muhît ilâ muhîti'l-muhît âliyyâtü't-tahdîs 'inde butrus el-bustânî, Mecelletü'l-mevrûs, cilt: 9, sayı: 1 (özel), 2021, sayfa aralığı: 163-174, s.172.Huri, Racülün sâbıkun liasrihî, $236 \mathrm{~s} . / 12$.

13 Dâgir, Mesâdirü'd-dirâseti'l-edebiyye, 2/183.

14 Carl Brockelmann, Geschichte der Arabischen litterature: Supplementband (Leiden: E.J. Brill, 1938), $2 / 768$.

15 el-Bustânî, Üdebâ; Hayreddin Ziriklî, el-A'lâm : Kamûsu terâcim li-eșheri'r-ricâl ve'n-nisâ min'el-Arab ve'l-müsta'rebîn ve'l-müsteșrikîn (Beyrut: Dârü'l-İlm li'l-Melayin, 1984), 2/59; Ömer Rızâ Kehhâle, elMüstedrek alâ Mu'cemi'l-müellifîn : Terâcimü musannifi'l-kütübi'l-Arabiyye (Beyrut: Müessesetü'rRisâle, 1985), 151.

${ }^{16}$ Butrûs b. Bûlûs el-Bustânî, Nefîru Sûriye (Beyrut: Dâru Fikr li'l-Ebhâs ve'n-Neşr, 1990). 
rut'un ilk gayriresmî Arapça gazetesidir. Bunun dışında 1870 yılında oğlu Selim ve Nâsîf el-Yâzîcî ile birlikte kurduğu bilimsel makalelerden oluşan el-Cinân; ${ }^{17}$ siyaset, ekonomi ve edebiyat alanlarında hazırlamış olduğu el-Cinne; yayın hayatı dört yıl kadar süren el-Cüneyne isimli dergilerin bizzat kuruculuğunu ve yazarlığını üstlenmiştir. ${ }^{18}$ Kendisinden sonra öğrencileri (takipçileri) onun çalışmalarını devam ettirmiş ve birçoğu; ülkede yazar, gazeteci, siyasetçi olarak etkili görevler üstlenmiștir. ${ }^{19}$

el-Bustânî bir filozof, bilim adamı ya da siyasi bir lider değildir. Özünde bir eğitimci, dilbilimci, ansiklopedist ve sosyal reformcudur. Modernleşme mesajını, zamanının potansiyellerini göz önünde bulundurarak olumlu, pratik ve barışçıl yollarla iletmiştir. Arap edebiyatının yeniden canlanmasıyla Batı'nın kültürel genişlemesi karşısında Suriye'yi kabul edilmiş ve saygı duyulan bir haklar merkezi olarak tahayyül etmiştir. 0 , düşüncesine ansiklopedik bir statü kazandıran vizyonu ve dengeli duruşu ile öne çıkmış; böylece öncü (râ'id) ve eğitimci (mu'allim) unvanlarını gerçekten hak etmiştir. ${ }^{20}$ Müellif tüm bu eğitim faaliyetleri ile meşgulken kalp krizi sonucu 1 Mayıs 1883'de 64 yaşında Beyrut'ta vefat etmiştir. ${ }^{21}$

Butrûs el-Bustâni yazılarında lafızlardan çok anlamlara önem vermiş ve zorlamadan uzak akıcı bir üsluba yönelmiștir. Bu yönüyle İbn Haldûn'un takipçisidir. Fakat doğru tabirleri yerli yerinde kullanmada onun kadar başarılı olamamıştır. ${ }^{22}$

\section{Reformist Düşünce Yapısı}

Bâbıâli Şubat 1856'da ünlü reform fermanı olan Hatt-ı Hümâyun'u ${ }^{23}$ yayınladığı zaman Butrus, bunun İmparatorluğun tebaasını devletin sosyal ve siyasi yapısıyla bütünleştirmeye yönelik gerçek bir adım olduğunu hemen anlamış, bu konuda destekleyici yazılar yazmıştır. Bu fermanın misyonerlik düşüncesine dayandığını savunanlara karşı durumun böyle olmadığını, devletin bu adımının gayrimüslimlerin marjinalliğini sona erdirmeyi hedeflediğini belirtmiştir. Misyonerler ise tikelci tavırları, Batı kültürüne vurgu yapmaları ve Arap kültürünü göz ardı etmeleriyle Suriye toplumunun sosyal ve kültürel ayrışmasına neden olmuşlardır. ${ }^{24}$

17 Stephen Sheeh, "Foundations of Modern Arab Identity", Epistemography of the Modern Arab Subject: Al-Mu'allim Butrus Al-Bustani's Khutbah Fi Adab-Al'Arab (Orange Grove Texts Plus, 2009), 71; Luvis Rızkullâh b. Yusuf b. Abdülmesîh el-Yesûî Şeyho, Târîhü'l-âdâbi'l-'Arabiyye fi'l-karni't-tâsi'i 'aşere ve'rub'i'l-evveli mine'l-karni'l-'işrîn (Beyrut: Dârü'l-Meşrik, 1991), 74-75.

18 Dâgir, Mesâdirü'd-dirâseti'l-edebiyye, 2/183-84.

${ }^{19}$ Raffoul, Butrus al-Bustanî Study of his Life, Achievements and Ideas, 190.

20 Raffoul, Butrus al-Bustanî Study of his Life, Achievements and Ideas, 193-194.

21 el-Bustânî, Kevserü'n-nüfûs, 344; Tarrâzî, Târîhu's-slhâfeti'l-'Arabiyye, 1/191; Ahmed İskenderî, elMufassal fi'l-usûri'l-kadîme ve'l-vasîta ve'l-hadîse, thk. Hasan Hallâk (Beyrut: Dâru İhyai'l-Ulûm, 1994), 614.

22 Tarrâzî, Târîhu's-sıhâfeti'l-'Arabiyye, 1/91; Dâgır, Mesâdirü'd-dirâseti'l-edebiyye, 2/182; el-Bustânî, Kevserü'n-nüfûs, 343.

23 Osmanlı diplomatiğinde padişahın kendi el yazısı ile yazılmış emirleri için kullanılan bir tabir.

${ }^{24}$ Raffoul, Butrus al-Bustanî Study of his Life, Achievements and Ideas, 181. 
Onun argümanı Arapların Batı ile sadece siyasi, sosyal ve kültürel değil, aynı zamanda ontolojik bir mücadele içinde olması gerektiği yönündedir. Yani Batı'nın eleștirel ya da tasvip edici değerlendirme kaygısı, Arapların kimliklerini tanıma mücadelesi içinde olduklarını gösterir. ${ }^{25}$ Başka bir deyişle, el-Bustânî'nin gözünde bu bir kader meselesidir. Daha büyük bir varlığın (Arap-Suriyeli ve Osmanlı) ayrılmaz bir parçası olmak ya da onunla sürekli çatışma içinde olmak arasında bir seçimdir. 0, ihtiyatlı bir şekilde ilk alternatifi seçmiş ve pek çok Suriyeli de onu takip etmiştir. ${ }^{26}$ Çünkü onun nazarında bireysel makro-farkındalığın (daha geniș, daha soyut bir bölgeye ait olma duygusu) oluşumuna ciddi sınırlar getiren kitle iletişiminin ve kültürünün yokluğunda insanlar, doğrudan tanıdıklarına ve topluluğun tüm üyeleriyle olmasa da çoğuyla olan bağlantılarına güvenirler. Bu tür yapılar duygusal sosyalleşmenin alternatiflerden yoksundur ve aidiyet odağı yerel unsurlarla sinırlıdır. ${ }^{27}$

Halbuki aralarındaki büyük farklılıklara rağmen Osmanlıcılık, Panislamizm, Pantürkizm gibi fikir akımları devlet için sağlam bir temel bularak emperyal gerilemeyi durdurmaya çalışmıştır. Bunu akılda tutarak Osmanlı İmparatorluğu'nun son dönemlerinde aidiyet sağlamaya yönelik aşağıdaki argümanları değerlendirdiğini, en azından denediğini, biliyoruz:

1. Ulus, bir dili ve dini paylaşan insanlardan oluşur. Sonuç olarak, aynı kültürü paylaşırlar (folklor, gelenekler, değerler, yaşam biçimi vb.).

2. Bu insanlar aynı soydan (geçmişten) ve kaderdendir (gelecekten). Zamansal bir süreklilik üzerinde bulunurlar.

3. Bir ulus olarak gelişmek için kendilerine ait bir devlete, mekânsal bir sürekliliğe ihtiyaçları vardır.

el-Bustânîyye göre yukarıdaki maddelerden birincisi, vatanseverlik için merkezîdir. Oysa ikincisi hem milliyetçilik terimi adına hem de ideolojisinde dikkatle ulusun arkasına gizlenmiş bir yapıdır. Üçüncüsü ise daha toparlayıcı bir ideoloji olmakla birlikte geliştirilmesi gereken bir düşüncedir. Nitekim İmparatorluk statükosunun korunmasında en büyük paya sahip olan Osmanlı Türk seçkinlerini incitecek tarzda bu sürecin evreleri, geçiş dönemi elitist bir makro kavram olan yurtseverliğin evriminin incelenmesiyle en sağlıklı șekilde ortaya konulabilir. Suriyeli yazar, ulus-ümmet, millet-cinsiyet ve halk-kavim düalitesi şeklinde tanımladığı birlikteliği, aynı ülkede yaşama ve aynı dili konuşma entegrasyonuna indirgemiştir. Bu bağlamda bir milliyet seçmek, kutsal bir kader meselesinden öte pratik bir gereklilik ve özellikle Arap olanın modernite karşısındaki rahat manevra alanıdır. ${ }^{28}$

Kendisi için devlet düşmanı, ayaklanmacı ithamlarında bulunanlara karşı 1856 fermanını gayrimüslimlere "refah fermanı" olarak değerlendirmiş ve bu fer-

25 Stephen Paul Sheehi, "Inscribing the Arab Self: Buțrus al-Bustānī and Paradigms of Subjective Reform”, British Journal of Middle Eastern Studies 27/1 (2000), 22.

26 Abu-Manneh, "The Ideas of Butrus", 289; Raffoul, Butrus al-Bustanî Study of his Life, Achievements and Ideas, 180.

27 Stephanov, "Butrus Al-Bustani, Mehmed Said Pasha and Ziya Gokalp”, 189.

28 Stephanov, "Butrus Al-Bustani, Mehmed Said Pasha and Ziya Gokalp”, 191, 205. 
manı halkına bahşeden Sultan Abdülmecid'e şükran ve bağlılığını ifade etmiştir. Gerçekten de el-Bustânî için eşit medeni ve siyasi hakların verilmesi, Suriye tarihinde yeni bir çağın açılması demektir. ${ }^{29}$ Nitekim el-Cinne'deki "Geçmişin Politikası" isimli başyazında, Bâbıâli'nin eski mezhepçi politikasından vazgeçip ülkesinde yaşayan bütün vatandaşları kapsayan bir özgürlük prensibi benimsediğini dile getirmiştir. Butrus el-Bustânî, esas itibariyle elitist bir makro kavram olarak vatanseverliği ön planda tutmuş ve kitle ölçeğinde nasıl empoze edildiğinden çok, teorik olarak nasıl inşa edildiğini çevresine anlatmaya çalıșmıştır. ${ }^{30}$ Ona göre bu davranış bölge düzeyinde eş zamanlı olarak yankı bulacak ve toplum arasındaki ayrışma, dinî unsurlara değil olsa olsa kültürel ve dilsel temellere dayalı küçük farklılıklar şeklinde cereyan edecektir. Öte yandan el-Bustânî̀ye göre böyle bir dayanışmanın kültürel homojenlik eksikliği dil alanı tarafından beslenince sadece Müslümangayrimüslim arasında değil, aynı zamanda Hristiyan topluluklar arasında da mezhepsel gruplaşma ortadan kalkmış olacaktır. Bu kolektif bilinç, sosyolojik açıdan birçok problemin önüne geçmiş ve vatanseverlik duyguları üretmenin önemli bir aracı haline gelmiştir. Mütefekkir, ortaya koyduğu ideolojisinde iki yaklaşım sergiler: Birincisi, Suriye içinde bütünleștirici bir kültürün oluşturulması için etnik hiçbir engel yoktur. Bu bize İslam'da yüksek sosyal statü elde etmek için etnik engellerin bulunmadığını hatırlatır. ${ }^{31}$ İkincisi ise -din ve mezhep fanatizmini eleştirse de- evrensel bir kültür ortaya koyabilmek için dinî imgeler kullanmada bir sakınca yoktur. Nitekim Hz. Peygamber'e atfedilen, "Vatan sevgisi imanın gereğidir"32 şeklindeki bir sözü makalelerinde kullanması bahsi geçen duygunun dışavurumudur. ${ }^{33}$ Buradan anlaşıldığı kadarıyla el-Bustânî'nin kültür nosyonu, geleceğe dönük Suriye'nin kültürel kaleydoskopu objektifinden, din dışı inşa edilmiş gibi görünse de dinî argümanları göz ardı etmeyen bir tanımı kapsamaktadır.

\section{Dillerin Babil'i}

el-Bustânî, Şubat 1859'da Beyrut'ta, Arap dili ve kültürünün canlandırılması için çağrıda bulunduğu "Arap Edebiyatı Üzerine" isimli konferansında dinleyicilerine, çeşitli ulusların dillerini Araplar arasında yaymakla meşgul olduklarını; Arapların ise "ana dillerine dikkat etmeden yabancı dil öğrenmeye büyük bir eğilim gösterdiğini" söyleyerek bir tehlikeye dikkat çekmiştir. Bu duruma çare sadedinde dili modern çağın gereksinimlerine uyarlamanın gerekliliğini dile getirmiştir. Ona göre

29 al-Bustani, The Clarion of Syria, 28.

30 Stephanov, "Butrus Al-Bustani, Mehmed Said Pasha and Ziya Gokalp”, 190.

31 Ebû Abdullah Ahmed b. Muhammed eş-Şeybânî Ahmed b. Hanbel, el-Müsned, thk. Ahmed Muhammed Şâkir (Kahire: Dâru'l-Hadîs, 1416), 5/411; Ebû Abdillâh Muhammed b. Yezîd el-Kazvînî İbn Mâce, Sünenü İbn Mâce, thk. Muhammed Fuâd Abdülbâkî (Kahire: Dârü İhyâi'l Kütübi'l-'Arabiyye, ts.), Hudûd, 3.

32 Bu söz sahîh hadîs kaynaklarında geçmemektedir. Zayıf hatta alimlerin kahir ekseriyeti mevzû olduğu yönünde görüș bildirmişlerdir. Bk. Ebü’l-Hasen Nûrüddîn Alî b. Sultân Muhammed el-Herevî Aliyyü'l-Kârî, el-Esrârü'l-merfû́a fi'l-ahbâri'l-mevdûca, thk. Muhammed b. Lütfi es-Sabbağ (Beyrut: Müessesetü'r-Risâle, 1971), 180.

33 Abu-Manneh, "The Ideas of Butrus", 291. 
dilin öğrenilmesini kolaylaştırmak ve daha arzu edilir kılmak için dil ile birlikte dilbilgisi de "yeniden düzenlenmelidir". Arapça, Latince gibi ölü bir dil haline gelmemeli, diye ekler müellif. Bu gerçekleşir ve yerel lehçeler edebî dilin yerini alırsa "Araplar için bundan daha büyük bir kayıp olmayacă̆ı" uyarısını tekrarlamıştır. Arapçanın modern bir öğrenim dili haline gelmesi konusunda endişeli olan elBustânî, yaşamının on yıldan fazlasını Muhît el-Muhît isimli sözlüğü derlemekle geçirmiştir ki onun bu gayreti "Kâmûs nâmûstur"34 düşüncesini ortaya koyan önemli bir düsturdur. Bu kapsamda Arapça sözlüklerin bilinmeyen, telaffuzu zor olduğu için veya başka sebeplerle artık kullanılmayan ve ölü denilebilecek kelimelere yer vermesini bir kusur olarak görmektedir. Bu tür kelimeleri vücuttaki çıbana benzeten el-Bustânî, sözlüklerin artık Arapçayı bu tür atıl kelimelerden kurtarması gerektiğini savunmaktadır. ${ }^{35}$ Butrus, böylesi istenmeyen bir gelişmeye karşı koymak için uygun önlemi, Arap dilinin Osmanlı toprakları üzerinde koordineli bir şekilde hâkim kılınması gibi tipik bir milliyetçi bakış açısıyla açıklar görünmektedir. Fakat ona göre vatanseverlik ile milliyetçilik arasında ayrım yapma girişimlerinin çoğunun merkezinde dil unsuru vardır.

Arapların dil mücadelesinin yanında medeniyete katkıları da unutulmamalıdır. İçinde yaşadığı toplumu "eski bilimler ile modern bilimler arasında köprü" olarak niteleyen düşünür, halkını zihinsel tembellik konusunda suçlamış ve onlara sanat ve bilim kitaplarının basımı, süreli yayınların yayınlanması, kütüphanelerin açılması, okulların kurulması gibi diriliş ortamları önermiștir. Bu önerilerin semeresini kısa sürede alan el-Bustânî ve arkadaşları sayesinde artık Beyrut, Arap kültürünün merkezi haline gelmiştir. 1870'lerde özel mülkiyete ait matbaalar kurulmuş ve ciddi bilimsel çalışmalara imza atılmıştır. Hayatının sonbaharındaki sözlükbilimsel proje (Muhît el-Muhît), gelecek nesiller için modern Arap filolojisinin bir anıtıdır onun gözünde. Mukaddimesinde belirttiği gibi, bu sözlük "Bâdiyeyi, Arap-İslâm medeniyetinin Terra Prima'sı" olarak merkezden uzaklaştırma girişimidir. Leksikoloji telîfatında, Süryanice ve diğer Sami etimolojik miraslarını birleştirmenin yanında klasik Arapçanın kan kaybını durdurma ve saf Arap kültürünü elde etme ideali taşımıștır. Çünkü Ahmed Fâris Şidyâk'ın (ö. 1305/1887) da belirttiği gibi halkına şöyle haykırmıştır: Avrupalılar dillerini medeniyetlerinden, biz ise medeniyetimizi dilimizden edindik. ${ }^{36}$

"Arapça aracılığıyla bilginin yayılması" fikir akımının temel hedefi, devletin toprak bütünlügünü sağlamak olduğu kadar Arap diline yönelik motiveyi artırma şeklinde de anlaşılmıştır. Müellife göre Arapça, diğer yaşayan diller gibi sevilmeli ve öğrenilmelidir. Onun ihyası Araplar üzerine "farz-ı kifâye"dir. Çünkü dil, sadece bir öğrenme aracı değil, her şeyden önce ulusal kimliğin bir temelidir. ${ }^{37} \mathrm{Bu}$ bağlamda Suriye, dinlerin ve mezheplerin Babil'i olduğu gibi “Dillerin Babil”i haline de

\footnotetext{
34 Cemil Meriç, Bu Ülke (İstanbul: İletișim Yayınları, 2005), 86.

35 'Abdurrezzâk b. Ferâc es-Sâ'idî, Mevtü'l-elfâz fi'l-'Arabiyye (Medine: el-Câmi'atü'l-İslâmiyye, 1856), 459.

36 al-Bustani, The Clarion of Syria, 33-34.

37 Abu-Manneh, “The Ideas of Butrus", 291-293.
} 
getirilmemelidir.

\section{Osmanlıcılık Düşüncesi}

Klasik Osmanlı yönetim sisteminde imparatorluğun nüfusu, itikadî bir yapı arz etmekteydi. Geleneksel millet sistemi olarak bilinen bu bölünmede, Müslümanlar ve gayrimüslimler (Hristiyanlar ve Yahudiler), dinî liderlerinin özerk idari, adli, mali ve manevi yönetimi altındaydılar. İnanca dayalı bu sosyal yapı, SünniMüslüman Osmanlı yöneticilerinin yüzyıllar boyunca imparatorluğun etnik ve dilsel olarak farklı nüfusunu yönetmedeki başarısının kilit unsurlarından biriydi. ${ }^{38}$ Ancak muharebe meydanlarındaki yenilgiler, merkezde yaşanan sosyo-politik istikrarsızlık ve emperyal ihtiyaçların mali olarak karşılanamaması, Osmanlı hükümdarlarını 18. yüzyılda imparatorluğun klasik örgütlenmesini değiştirmeye zorlamış ve onu Avrupa'ya göre modernize etmeye itmiştir. 19. yüzyılın ikinci çeyreğinde Tanzimat Fermanı'nın (1839) saray bahçesinde ilan edilmesi bu reformların başlangıç noktası olmuştur. Bu noktada şu unutulmamalıdır ki dönemi karakterize eden reformların amacı, yalnızca imparatorluk aygıtını güçlendirmek değil, aynı zamanda Avrupalı güçlerin siyasi ve askeri müdahalelerini engellemekti. Daha sonra yayınlanan Hatt-ı Hümâyun (1856) ise, tüm Osmanlı tebaasına, sınıfları ve dinleri ne olursa olsun eğitimde, hükümet atamalarında ve adalet yönetiminde eşitlik vaadinde bulunmuştur.

Bütün bu gelişmeler yaşanırken 1860'ın yaz aylarında Cebel-i Lübnan olayları, hemen ardından Şam olayları başlatıldı. ${ }^{39}$ Halkına oyuna gelmemeleri için sürekli telkinlerde bulunan Butrus, Osmanlı yönetimini bir yanda Hristiyan ya da Dürzi saldırganlığını, diğer yanda dıș müdahale ve tahakküm üzerinde bir kontrol olarak görüyordu. Bu olaylar yirmi bin kişinin hayatına mal olmakla ve otuz bin evi yakıp kül etmekle kalmadı aynı zamanda Osmanlı Islahat Fermanı'nın ülkenin kalkınması için sağladığı altın fırsatı da tehlikeye atmıştı. el-Bustânî’nin kardeş katli felaketine ilk tepkisi, Lübnan Dağı'nın her yerinden ve Şam'dan gelen binlerce mülteci için uluslararası yardım çabalarını organize etme şeklinde oldu. Dağın alev topu halinde yükselişini izlerken, eski Mârûnî halkının çektiği acılar, ilk taşı kimin attığı sorusundan bağımsız içini acıtıyordu. ${ }^{40}$

"Suriye" nitelemesi, Osmanlıcılık doktrininin uygulanmasında, el-Bustânî gibi önde gelen bir düşünürün bile çözemediği bölgesel ve küresel arasındaki içsel gerilimlerin varlığına işaret etmesi bakımından daha da ironiktir. Bu nedenle onun hayatı, Suriye yurtseverliği ile Osmanlıcılık arasında bir çizgide yürümenin öykü-

38 M. Fatih Çalıșır, "Ottomanısm In The Age Of Dısıntegratıon: Namık Kemal And Butrus Al-Bustanı”, Tarih Okulu Dergisi 2009/III (2009), 60-61.

39 İnanç faktörü kullanılarak Avrupa Devletlerinin, Osmanlı yönetiminde bulunan bölgede kendi çıkarlarını gözetme adına 1860-61 yıllarında çıkardıkları ayaklanma hareketidir. Bk. Olcay Duman, "Bir Orta-Doğu Buhranı Cebel-i Lübnan Olayları (1860-61)”, Mustafa Kemal Üniversitesi Sosyal Bilimler Enstitüsü Dergisi 3/5 (04 Mart 2014), 4.

40 al-Bustani, The Clarion of Syria, 29. 
südür. Birincisi her zaman en az ikincisi kadar yüreğine yakındır. ${ }^{41}$ Kendisine göre topyekûn olma, bölgesel bir bileșenle değil kültürel bir bileșenle başlamaktadır. Osmanlıcılıkta tam da bu eksiktir. Bu düşüncenin en büyük zaafı kültürel olarak boş olmasıdır. Osmanlıcılık etnik bileșeni marjinalleştirmeye ve devlet-toprak bileşenine aşırı vurgu yapmaya çalışırken, onun öngörüsü kültürel homojenleşme ve makrokültürün toplumu cemiyet olmaya götürmede daha isabetli bir deva olduğudur. Zira sağduyulu olma özelliğini gösteren ilim adamı, bu olaylardan bir yıl önce söz konusu tehlikelere işaret etmiş ve dilden sonra ikinci bir ortak ideal çağrısında bulunmuştu: Anavatan. Olayların hemen ardından ise yayınlamaya başladığı Nefîr Sûriye dergisinde sade ve samimi bir üslupla şöyle seslenmektedir:

Ey vatan evlatları! Aynı suyu içer, aynı havayı solur, aynı dili konuşursunuz. Üzerinde yürüdüğünüz toprak, ortak çıkarlarınız ve adetleriniz birdir. Suriyelilerin geri kalmışlı̆̆ yönetimle ilgili bir durum değil, aralarındaki birlik ve sevgi eksikliğinin bir neticesidir.42

$\mathrm{Bu}$ ifadelerinin hemen ardından Peygamber'e atfedilen "Vatan sevgisi imanın gereğidir" sözünü aktarmak suretiyle vatan sevgisini mezhep taassubunun yerine koyanların Suriye'ye ait olmadıklarını haykırmıștır. On yıl sonra yayınladığı elCinân dergisinde de birlik ve devlete bağlılık çağrılarını yapmak suretiyle sözlerin sağlam duruşu olması gerektiğini göstermiştir. ${ }^{43}$

Çağdaş bir biyografi yazarı olan Butrus, yalnızca ülkesine olan sevgisinde bir fanatiktir. Onun bu ulusçu yaklaşımının devletçiliğine halel getirmediğini Osmanlı yönetimi de fark etmiş, Fuad Paşa'nın Beyrut ve Şam’ı ziyareti sırasında (1861) kendisine kültürel ve bilinçlendirici yayınlarına katkı sadedinde yirmi beş bin kuruş ödül ve Mecid Nişanı takdim edilmiştir. Özellikle dönemin sadrazamı ve Suriye valisi Mehmed Reşid Paşa, kendisi ile yakın diyalog sergilemiş ve bu kültür elçisine devlet adına sahip çıkmıştır. Hatta Reşid Paşa, 1865'te Şam şehrinde Suriye adını taşıyan Türkçe-Arapça resmî bir gazete kurmuştur. ${ }^{44}$ Reşid Paşa'nın valiliği döneminde özgürce devletini savunan ve halkı bu konuda bilinçlendiren Butrus, herhangi bir Avrupa egemenliğini Suriye'nin geleceği için dezavantajlı olarak gören birkaç Suriyeli Hristiyan'dan biridir. Mahmud Nedîm'in Sadrazamlığa yükselmesinden sonra (Eylül 1871) Reşid Paşa'nın geri çağrılmasıyla bölgede devletçilik motivasyonu azalmıştır. Bunun üzerine el-Bustânî'nin yazıları iç politikadan dünya siyasetine doğru kaymıştır. Başyazı temalarının değişme sebebini Mahmud Nedîm'in basın sansürü olarak açıklayan yazar "Bu gibi durumlarda susmak daha iyidir" yorumunu yapmıștır. Fakat bu inkıta döneminde kendi adına siyasi sağduyu, öngörü ve devlete bağllı̆ğ savunmaktan da geri durmamıştır. el-Bustânî'nin hem bölgesel hem de imparatorluk düzeyinde siyasi iklim değiștiğinde yazılarının

\footnotetext{
41 Stephanov, "Butrus Al-Bustani, Mehmed Said Pasha and Ziya Gokalp”, 197.

42 el-Bustânî, Nefîru Sûriye, 10.

43 Abu-Manneh, "The Ideas of Butrus", 293; Stephen Paul Sheehi, "Inscribing the Arab Self: Buțrus alBustān̄ and Paradigms of Subjective Reform”, British Journal of Middle Eastern Studies 27/1 (2000), 17.293

44 Stephanov, “Butrus Al-Bustani, Mehmed Said Pasha and Ziya Gokalp”, 199.
} 
içeriğini ve tonunu değiştirdiği görülmektedir. Bu da edebî otosansüre varıncaya kadar müesses nizamın uygulamalarına karşı çımamak için son derece ihtiyatlı davrandığının göstergesi sayılabilir. ${ }^{45}$ Hamdi Paşa döneminde de basın yayının üzerinde baskı kurulmasının ardından (1874-75) ${ }^{46}$ yazılarına devam etmiş ve Sultan Abdülhamid'in meşrutiyetçilere karşı argümanını bütünüyle desteklemiştir. Ona göre ulusların reformu bir vuruşta elde edilebilecek bir zafer değildir.

Derin analizleri olan el-Bustânî'ye göre Fransız İhtilali "haklar çağının başlangıcıydı." Avrupa milletlerini haklarını savunma konusunda harekete geçiren "bu rûh bir asır sonra Doğu'ya nüfuz etti ve biz bunu hissettik" diye bitirdi birçok yazısını. Bütün bu hak savunuculuğunun yanında el-Bustânî'nin demokratik bir rejimden veya anayasal bir hükümetten yana olduğu anlaşılmamalıdır. Aksine, daha çok doğu geleneğine bağll, halk içinde değil halk için bir hükümet düsturunu benimsemiştir. Zaten yaşadığı dönemde Osmanlı toplumunun demokratik yönetime yeterince hazır olmadığını şu sözleriyle ifade etmektedir:

Ülke önce buna hazırlanmalı. Bir temsilciler meclisi kurmaktansa, eğitimin yaygınlaştırılması ve yargı sisteminin reformu için kanunların çıkarılması tercih edilmelidir. Halk bu reformlar için yeterli bir bilgi düzeyine ulaştığında seçilmiş bir meclis fikri desteklenmelidir. Aksi halde seçenlerin eğitim seviyesi yükseltilmeden seçilmiş bir meclisin zararı, yararından büyük olacaktır. ${ }^{47}$

Özetlemek gerekirse Butrus el-Bustânî bir Protestan'dır, bir Suriye milliyetçisidir ve daha da önemlisi Osmanlı topraklarında ortaya çıkan resmî ideolojinin (Osmanlıcılığın) samimi bir destekçisidir. ${ }^{48}$ Hayatı boyunca "el-Muallim" unvanını hak edecek düzeyde bölgenin en iyi eğitimcisi olduğu gibi vefatından sonra da (1 Mayıs 1883) modern Suriye'nin en etkili fikir adamı olmayı başarmış bir kimliktir.

\section{Türk Edebiyatındaki Takipçileri}

Araştırmanın amaçları doğrultusunda bu başlık altında üç kilit şahsiyetin Butrus el-Bustânî, Namık Kemal ve Ziya Gökalp- telifatlarına ve faaliyetlerine yönelmek suretiyle hem ideoloji hem de edebî anlamda dönemin fikriyatına ișık tutulmaya çalışılacaktır. Nitekim mezkûr isimlerden el-Bustânî ve Namık Kemal, ıslahat döneminin ilk periyodunda farklı coğrafya ve kültüre ait vatan duygusunun fikri temsilciliğini yapmış, Ziya Gökalp ise ikinci periyotta milliyetçilik düşüncesini zirveye taşımıştır. Siyasi olarak taban tabana zit olsalar da edebiyat alanında ortaya koyduklarıyla edebi olanın farklılıkları nasıl erittiğini gözler önüne sermişlerdir. $\mathrm{Bu}$ isimler doğrudan siyasi bir bağlılığı olmayan, ancak öğretileri kendi zamanlarının sosyal ve politik gelişmelerini yansıtan önde gelen entelektüeller ve ideologlardır. Nihayetinde, düşünürlerin bu konfigürasyonu ilginçtir. Çünkü Butrus el-

\footnotetext{
45 Stephanov, "Butrus Al-Bustani, Mehmed Said Pasha and Ziya Gokalp”, 200.

${ }^{46}$ Lübnan'da yaşanan sansür hareketleri için bk. Selçuk Günay, "II. Abdulhamid Döneminde Suriye ve Lübnan'da Arap Ayrılıkçı Hareketlerinin Başlaması ve Devletin Tedbirleri”, Tarih Araştırmaları Dergisi 17/28 (1995), 85-108.

${ }^{47}$ Abu-Manneh, "The Ideas of Butrus", 299.

${ }^{48}$ Çalışır, "Ottomanısm In The Age Of Dısıntegratıon”, 60.
} 
Bustânî (Osmanlıcı) ve Ziya Gökalp (Milliyetçi) arasındaki eksik halkayı tamamlayan Namık Kemal olmuştur. Tabii ki söz konusu edipler arasında bu marjinalliği ilk ortaya koyan daha önce de belirtildiği gibi Butrus el-Bustânî olmuștur.

Kaotik bir dönemde Butrus el-Bustânî'nin Suriye bölgesinde yaptı̆̆ı ilmî çalışmalarla eş zamanlı olarak İstanbul'da kendilerine "Genç Osmanlılar" adını veren dikkat çekici bir grup ortaya çıkmıştır. Namık Kemal'in öncülüğ̈nü yaptığı bu grubun üyeleri, "diktatörel yönetimle, fildiși kulelerde yanlış politikalar üretmekle ve dalkavuk oligarşisi kurmakla" suçladıkları Ali ve Fuad Paşaların politikalarına karşı harekete geçmek için bir araya gelmiş aydınlardır. Halkın nabzını tutan bu grup Paşaların yönetim üslubunu eleştirmekle birlikte tıpkı Butrus'un yaptığı gibi Osmanlıcılık politikasını destekliyorlardı. Bâbıâli Tercüme Bürosu'ndaki Avrupa siyasi sistemleri ve imparatorluğun dış politikası hakkında sağlam bir bilgi birikimine sahip olmalarını sağlayan iş deneyimleri nedeniyle, vatandaşlık fikrine ve farklı dinî-etnik kökenleri korumak için pratik avantajlarına tamamen aşinaydılar. Bu nedenle vatandaşlık fikrinin itikadî kökleri olmadığı tezinden hareketle "laik" kavramını dinî gelenekle birleştirmek ve daha sonra onu gayrimüslimlerin sadakatine zarar vermeden imparatorluktaki Müslümanlar arasında yaygınlaştırma gayesi gütmüşlerdir. ${ }^{49}$

Suriye'de Butrus el-Bustânî'nin "Vatan Evlatları", Anadolu'da Namık Kemal'in "Vatan yahut Silistre" kavramları aslında eşdeğer siyasi ve edebî birer miras olarak karşımıza çıkmaktadır. Hem muhalif yapıları hem de edebî kaygıları, bu iki fikir adamının birbirlerinden ciddi derecede etkilendiklerini göstermektedir. Butrus'un yazılarını takip eden Namık Kemal, Tasvir-i Efkâr gazetesinin yazar ve editörlüğünü yapmış, fikriyatını Anadolu insanı ile paylaşmıştır. ${ }^{50}$ Edebî kabiliyetini vatan, hürriyet, bayrak gibi yeni kavramları yaygınlaştırmak için kullanan Kemal'in, Batı kökenli bu kavramları dönemin siyaset diline uyarlanmasında Butrus el-Bustânînnin katkısı büyüktür. Bu bağlamda mezkûr kavramları yayınlarında İslâm dünyası ile paylaşan Butrus el-Bustânî, bir taraftan bölgesini sakinleștirmeye çalışıyor bir taraftan da Namık Kemal gibi diğer bölgelerdeki önde gelen fikir adamlarına İslam tarihi ile Osmanlı yönetimi arasında bir sentez yapma usulünü göstermiş oluyordu. ${ }^{51}$ Bundan mülhem Kemal, geliştirdiği sentez üslubu ile makalelerinde Halife Ömer'in ve Kanuni Sultan Süleyman'ın büyüklügünü, Fârâbî ve Gazzâlî'nin vatanseverliğini benzer kompozisyonla okuyucularına sunuyordu. ${ }^{52}$

Başta el-Bustânînnin, sonrasında Namık Kemal ve Ziya Gökalp'in de ortaya koyduğu anavatanın bu duygusal tanımı, "kişinin kendisini onun için ölmeye adadığı bir ülke" anlamına gelen Fransızca "patrie" kavramıyla eşdeğer gibiydi. ${ }^{53}$ Zira

\footnotetext{
49 Çalışır, “Ottomanısm In The Age Of Disıntegratıon”, 62.

${ }^{50}$ Namık Kemal'in edebî kimliği ile ilgili detaylı bilgi için bk.M. Kaya Bilgegil, Harabat Karşısında Namık Kemal (İstanbul: İrfan Yayınevi, 1972); Kazım Yetiș, Namık Kemal'in Türk Dili ve Edebiyatı Üzerine Görüşleri ve Yazıları (İstanbul: Alfa Yayınları, 1996).

51 Bernard Lewis, The Political Language of Islam (Chicago: University of Chicago Press, 1991), 40.

52 Bernard Lewis, The Emergence of Modern Turkey (New York: Oxford University Press, 2002), 336.

53 Stephanov, "Butrus Al-Bustani, Mehmed Said Pasha and Ziya Gokalp", 90.
} 
19. yüzyll öncesi hem Anadolu hem de Arap coğrafyasında vatan, herhangi bir siyasi bağ olmaksızın doğup ikamet edilen yer anlamına geliyordu. Bu nedenle doğu insanı, bütün toprakları hükümdarların malı olarak görüyor, memleketin kendisine değil, idarecilerine vatan olarak bakıyordu. Netice itibariyle sakinlerinin kültürel ve siyasi kelime dağarcıklarında bu tür kavramların olmadığı bir toprakta Osmanlıcılık ve vatanseverlik fikrini öne çıkaranların işi biraz zor görünüyordu. ${ }^{54} \mathrm{Bu}$ zorluğu aşmak ve toplumu ikna etmek için vatan kavramını dinî duygularla tanımlayan ve yazılarına "Ey vatan evlatları!"55 hitabıyla başlayan Butrus karşısında Namık Kemal de "Vatan yahut Silistre"56 sloganı ile halka seslenmiştir. Tabiidir ki Butrus'un el-Cinân ve Nefîr Sûriye yayınlarına uygulanan sansür, Namık Kemal'in Vatan yahut Silistre'sinde de kendisini hissettirmiştir. Türk vatanseverliğini "aşırı yüceltme" gerekçesiyle oyunu durdurulmuş ve Kemal, Kıbrıs'a sürgün edilmiştir $(1873-76) \cdot{ }^{57}$

İki farklı coğrafyada yaşanan bütün bu serencam, Namık Kemal'in Lübnan'da yükselen eșitlik ve kardeşliğe dayalı "vatan" kavramından; Butrus elBustânî'nin ise Anadolu'dan duyulan "Osmanlıcılık” kavramından etkilendiğinin bir göstergesidir.

Osmanlıcılığı, etrafında güçlü bir devletin inşa edilebileceği sadakate dayalı alternatif arayışlar izler. Bu arayışların temelinde Osmanlı İmparatorluğunun artık ikincil ve dövülebilir bir devlet (hasta adam) betimlemesi yatmaktadır. Böylece "Pantürkizm", 19. yüzyılın ortalarında Osmanlı topraklarında kamuoyuna yansıyan bir başka ideoloji olmuştur. Bu fikir akımının ciddi savunucularından biri şüphesiz Ziya Gökalp'tir. Daha çok Ziya Gökalp mahlasıyla tanınan Mehmet Ziya (ö. 18761924), Diyarbakır'da devlet hizmeti geçmişine sahip bir ailede dünyaya gelmiştir. Sürgünlerle geçen hayatında siyasi duruşunu bastırır derecede popüler bir eğitim görevlisi, şair, gazeteci, sosyolog ve filozof olarak tanımlanır. ${ }^{58}$

Gökalp, Osmanlıcılığı "sosyolojik temellere dayanmayan, modası geçmiş, pratik olarak gerçekleştirilemez bir doktrin" olduğuna inandığ için reddeder. Ona göre artık siyasi veya kültürel birlikteliğin yerini milliyete bırakmanın zamanı gelmiştir. Fransız sosyolog Gabriel Tarde'nin teorilerinin ruhuna uygun olarak Gökalp, yeni çağın demode dil biçimlerinin ötesinde idol sosyoloğu Emile Durkheim'dan ödünç alınmış geleneksel kültürde, yani Türklük'te ve İslam'da aranacak yeni bir kolektif temsile ihtiyaç olduğunu savunur. Bu kapsamda 1913'te "Milliyetçilik İdeali: Üç Düşünce Akımı" başlıklı bir makale yayınlar ve burada Türklük, İslam ve moderniteyi uzlaștırmaya çalışır. Tabii ki Şerif Mardin'in de ifade ettiği gibi burada İslâm, Osmanlı'nın geleneksel inancından ziyade, toplumu bir arada tutan değerler dizisi olarak gerçek bir Durkheimcı anlamda ele alınmaktadır.

\footnotetext{
54 Çalıșır, “Ottomanısm In The Age Of Dısıntegratıon”, 63.

55 Abu-Manneh, "The Ideas of Butrus”, 293.

56 Namık Kemal, Vatan yahut Silistre (Ankara: Milli Eğitim Bakanlığı Yayınları, 1969).

57 Şerif Mardin, Yeni Osmanlı düşüncesinin doğuşu. (İstanbul: İletişim Yayınları, 1996), 327-331.

58 Stephanov, "Butrus Al-Bustani, Mehmed Said Pasha and Ziya Gokalp”, 220.
} 
Tıpkı Butrus ve Namık Kemal gibi İslam'ın vatanseverlik lehine çalışan bir faktör olduğuna inanmaktadır. Fakat bu iki fikir adamının aksine Gökalp, ilk kez çağdaş Osmanlı Devleti'nin sınırlarının dışında düşünmeye başlar. Kendi ifadesiyle "Devlet kendi başına var olan bir güç değildir." 59

Gökalp, el-Bustânînnin yukarıda verdiğimiz üç ilkeli tanımına harfiyen uyan ulusal bir yapı benimsemekle birlikte muasırlarından farklı olarak Osmanlı İmparatorluğu'na bir alternatif sadedinde Turan idealini de dillendirmektedir. ${ }^{60}$ Yine Bernard Lewis'in işaret ettiği gibi Gökalp, öğretilerini dayandırdığı sosyolojiyi bir tür din olarak, "ahlaki, sosyal, politik ve hatta dinî sorunlar üzerinde yarı açılanmış bir otorite kaynağı" olarak ele alır. ${ }^{61}$ el-Bustânî'nin zaman zaman görmezden geldiği “aile, köy ve kasaba” gibi micropatria dediğimiz küçük kültürel yapılara dikkat çeken Gökalp, makrovatanseverlik olarak adlandırılan ideali de fedakarlığın ardındaki "yoğun ahlaki duygular" olarak tanımlar. Yani Butrus, dilsel bir birlik arzularken Gökalp, dilin de içinde olduğu bütün bir ortak değerler sistemi tasavvurunda bulunur.

Bütün bu tartışma ve argümanlar dil, kültür ve ideoloji farklılığına rağmen edebî ve fikrî anlamda Butrus el-Bustânî, Namık Kemal ve Ziya Gökalp'in birbirlerinden ciddi derecede etkilendiklerini göstermektedir.

\section{Sonuç}

Mârûnî bir ailenin mensubu olan Butrus b. Bûlûs el-Bustânî Beyrut-Dibbiye doğumlu olup gençlik çağının en verimli yıllarını Lübnan'ın kozmopolit ortamında geçirmesi ve farklı kültür atmosferlerinde bulunması sebebiyle 19. yüzyıl Arap dünyasının en dikkat çeken fikir adamlarından biri olmuştur. Araştırmamıza konu olan Butrus el-Bustânî, oldukça marjinal bir Osmanlı edebiyatçısıdır. Çok yönlü, sivri dilli ve reformist edibin ele aldığı konular ve Osmanlı topraklarındaki takipçileri ile ilgili tespit ettiğimiz hususlar maddeler halinde şöylece sıralanabilir:

- Butrus b. Bûlûs el-Bustânî, Arap dilinin dünya çapındaki ilmî ve edebî uyanışında önemli payı olan fikir adamlarındandır.

- Bustânî tarafından savunulan eğitim projesi, toplumun farklı kesimleri arasındaki uyumu güçlendirmeyi amaçladığından misyonlarınkinden farklılık arz etmektedir.

- Kör fanatizme eleştirel yaklaşımı bazı guruplar nazarında devlet yönetimine muhalif bir tavır gibi algılansa da aksine o, Osmanlı devletinin yanında durmuş ve yönetenlere karşı bir devrim çağrısında bulunmamıştır.

- Sultan Abdülaziz, bu okulu kurma başarısından dolayı el-Bustânî'ye "Mecid Nişanı" vermiş; akabinde bu çabaya destek olarak Osmanlı valileri tarafından sık sık ziyaret edilmiștir.

- Kendisine göre topyekûn olma, bölgesel bir bileşenle değil kültürel bir bi-

\footnotetext{
${ }^{59}$ Ziya Gökalp, Makaleler I. (Ankara: Kültür Bakanlığı Yayınları, 1976), 54-58.

60 Gökalp, Makaleler I., 55.

61 Stephanov, "Butrus Al-Bustani, Mehmed Said Pasha and Ziya Gokalp”, 222.
} 
leşenle başlamaktadır. Osmanlıcılıkta tam da bu eksiktir.

- Butrûs el-Bustâni yazılarında lafizlardan çok anlamlara önem vermiş ve zorlamadan uzak akıcı bir üsluba yönelmiştir. Bu yönüyle İbn Haldûn’un takipçisidir.

- Arapların Batı ile sadece siyasi, sosyal ve kültürel değil, aynı zamanda ontolojik bir mücadele içinde olması gerektiği yönündedir.

- Suriyeli yazar, ulus-ümmet, millet-cinsiyet ve halk-kavim düalitesi şeklinde tanımladığı birlikteliği, aynı ülkede yaşama ve aynı dili konuşma entegrasyonuna indirgemiştir.

- $\quad$ Ona göre Avrupalılar dillerini medeniyetlerinden, Araplar ise medeniyeti dillerinden edinmişlerdir. Bu nedenle teyakkuz halini bırakmadan Suriye dinlerin ve mezheplerin Babil'i olduğu gibi "Dillerin Babil”i haline de getirilmemelidir.

- $\quad$ el-Bustânî ve Namık Kemal, ıslahat döneminin ilk periyodunda farklı coğrafya ve kültüre ait vatan duygusunun fikri temsilciliğini yapmış, Ziya Gökalp ise ikinci periyotta milliyetçilik düşüncesini zirveye taşımıştır.

- Suriye'de Butrus el-Bustânînnin "Vatan Evlatları", Anadolu'da Namık Kemal'in "Vatan yahut Silistre" kavramları aslında eşdeğer siyasi ve edebî birer miras olarak karşımıza çıkmaktadır.

- İki farklı coğrafyada yaşanan fikri mücadele, Namık Kemal'in Lübnan'da yükselen eşitlik ve kardeşliğe dayalı "vatan" kavramından; Butrus elBustânî̀nin ise Anadolu'dan duyulan "Osmanlıcılık" kavramından etkilendiğinin bir göstergesidir.

- Butrus'un fikirlerinden etkilenen Ziya Gökalp ise Osmanlıcılığı "sosyolojik temellere dayanmayan, modası geçmiş, pratik olarak gerçekleştirilemez bir doktrin" olduğuna inandığı için reddeder.

- Gökalp, el-Bustânî'nin idealine harfiyen uyan ulusal bir yapı benimsemekle birlikte ondan ve Namık Kemal'den farklı olarak Osmanlı İmparatorluğu'na bir alternatif sadedinde Turan idealini de dillendirmektedir.

- Bütün bunlar göstermektedir ki aralarındaki dil, kültür ve ideoloji farklılığına rağmen bu üç mütefekkir edebî ve fikrî anlamda birbirlerinin takipçisi olmuşlardır.

Author Contributions / Yazarların Katkısı: This article is a work with twoauthors. The contribution of the aforementioned authors to the preparation of the article is equal. / Bu makale, iki yazarlı bir eserdir. Makalenin hazırlanmasına söz konusu yazarların katkısı eşittir.

Funding / Finansman: This research received no external funding. / Bu araştırma herhangi bir diş fon almamıștır.

Conflicts of Interest / Çıkar Çatışması: The author declare no conflict of interest. / Yazar, herhangi bir çıkar çatışması olmadığını beyan eder. 


\section{Kaynakça}

Abu-Manneh, Butrus. "The Christians Between Ottomanism and Syrian Nationalism: The Ideas of Butrus Al-Bustani". International Journal of Middle East Studies 11 (1980), 287-304.

Ahmed b. Hanbel, Ebû Abdullah Ahmed b. Muhammed eş-Șeybânî. el-Müsned. thk. Ahmed Muhammed Șâkir. 8 Cilt. Kahire: Dâru'l-Hadîs, 1416.

Aliyyü'l-Kârî, Ebü'l-Hasen Nûrüddîn Alî b. Sultân Muhammed el-Herevî. el-Esrârü'l-merfû́a fi'l-ahbâri'l-mevdû́a. thk. Muhammed b. Lütfi es-Sabbağ. Beyrut: Müessesetü'r-Risâle, 1. Basım, 1971.

Bilgegil, M. Kaya. Harabat Karşısında Namık Kemal. İstanbul: İrfan Yayınevi, 1972.

Brockelmann, Carl. Geschichte der Arabischen litterature: Supplementband. Leiden: E.J. Brill, 1938.

Bustani, Butrus al-. The Clarion of Syria: A Patriot's Call against the Civil War of 1860. çev. Jens Hanssen - Hicham Safieddine. California: University of California Press, 2019.

Bustânî, Butrûs b. Bûlûs el-. Nefîru Sûriye. Beyrut: Dâru Fikr li'l-Ebhâs ve'n-Neșr, 1990.

Bustânî, Butrûs b. Süleymân el-. Üdebâ'ü 'l-'Arab fi'l-Câhiliyye ve sadri'l-İslâm. Kahire: Müessesetü Hindî, 2014.

Bustânî, Fu'âd Afrâm. el-Mu'allim Butrus el-Bustânî. Beyrut: el-Mektebetü’s-Şarkiyye, 1975.

Bustânî, Mülhim İbrahim el-. Kevserü'n-nüfûs. Lübnan, 1954.

Çalışır, M. Fatih. "Ottomanısm In The Age Of Dısıntegratıon: Namık Kemal And Butrus AlBustanı". Tarih Okulu Dergisi 2009/III (2009), 59-68.

Dâgır, Yûsuf Es'ad. Mesâdirü'd-dirâseti'l-edebiyye. Beyrut: el-Menşûrâtü'l-Câmia, 1983.

Duman, Olcay. "Bir Orta-Doğu Buhranı Cebel-i Lübnan Olayları (1860-61)". Mustafa Kemal Üniversitesi Sosyal Bilimler Enstitüsü Dergisi $3 / 5$ (04 Mart 2014), 4.

Ergin, Ali Şakir. "Bustânî, Butrus b. Bûlus". TDV İslâm Ansiklopedisi. 6/473. İstanbul: TDV Yayınları, 1992.

Gökalp, Ziya. Makaleler I. Ankara: Kültür Bakanlı̆̆g Yayınları, 1976.

Günay, Selçuk. "II. Abdulhamid Döneminde Suriye ve Lübnan'da Arap Ayrllıkçı Hareketlerinin Başlaması ve Devletin Tedbirleri". Tarih Araștırmaları Dergisi 17/28 (1995), 85-108.

Huri, Yusuf Kazma. Racülün sâbıkun li-asrihî: el-mu'allim Butrus el-Bustânî. Beyrut: Bisân li'n-Neșr, 1995.

İbn Mâce, Ebû Abdillâh Muhammed b. Yezîd el-Kazvînî. Sünenü İbn Mâce. thk. Muhammed Fuâd Abdülbâkî. 2 Cilt. Kahire: Dârü İhyâi'l Kütübi'l-'Arabiyye, ts.

İskenderî, Ahmed. el-Mufassal fi'l-usûri'l-kadîme ve'l-vasîta ve'l-hadîse. thk. Hasan Hallâk. Beyrut: Dâru İhyai'l-Ulûm, 1994.

Kehhâle, Ömer Rizâ. el-Müstedrek alâ Mu'cemi'l-müellifîn: Terâcimü musannifi'l-kütübi'lArabiyye. Beyrut: Müessesetü'r-Risâle, 1985.

Kemal, Namık. Vatan yahut Silistre. Ankara: Milli Eğitim Bakanlığı Yayınları, 1969.

Lewis, Bernard. The Emergence of Modern Turkey. New York: Oxford University Press, 2002.

Lewis, Bernard. The Political Language of Islam. Chicago: University of Chicago Press, 1991.

Mardin, Şerif. Yeni Osmanlı düşüncesinin doğuşu. İstanbul: İletişim Yayınları, 1996.

Meriç, Cemil. Bu Ülke. İstanbul: İletişim Yayınları, 2005.

Ömer, Ahmed Muhtâr. el-Bahsu'l-luğavî 'inde'l-'Arab. Kahire: Âlemü'l-Kütüb, 1988.

Raffoul, Pierre Georges. Butrus al-Bustanî Study of his Life, Achievements and Ideas. Sydney: The University of Sydney, 2001.

Sâ'idî, 'Abdurrezzâk b. Ferâc. Mevtü'l-elfâz fi'l-'Arabiyye. Medine: el-Câmi'atü'l-İslâmiyye, 1856.

Serkîs, Yûsuf b. İlyân b. Mûsâ. Mu'cemü'l-matbû'âti'l-arabiyye ve'l-mu'arrabe. 1-2 Cilt. Matbaatü Serkîs, 1928.

Sheeh, Stephen. "Foundations of Modern Arab Identity". Epistemography of the Modern Arab Subject: Al-Mu'allim Butrus Al-Bustani's Khutbah Fi Adab-AI'Arab. Orange Grove Texts Plus, 2009. 
Sheehi, Stephen Paul. "Inscribing the Arab Self: Buțus al-Bustānī and Paradigms of Subjective Reform". British Journal of Middle Eastern Studies 27/1 (2000), 7-24.

Stephanov, Darin. "Patriotism in Transition: The Thought of Butrus al-Bustani, Mehmed Said Pasha and Ziya Gokalp". Butrus Al-Bustani: Spirit of the Age. ed. Beshara Adel. Melbourne: CreateSpace Independent Publishing Platform, 2014.

Şeyho, Luvis Rızkullâh b. Yusuf b. Abdülmesîh el-Yesûî. Târîhü'l-âdâbi'l-'Arabiyye fi'l-karni'ttâsi'i 'așere ve'rub'i'l-evveli mine'l-karni'l-'işrîn. Beyrut: Dârü'l-Meşrik, 1991.

Tarrâzî, Phillippe De. Târîhu's-sıhâfeti'l-'Arabiyye. Beyrut, 1913.

Yetiș, Kazım. Namık Kemal'in Türk Dili ve Edebiyatı Üzerine Görüşleri ve Yazıları. İstanbul: Alfa Yayınları, 1996.

Ziriklî, Hayreddin. el-A'lâm: Kamûsu terâcim li-eșheri'r-ricâl ve'n-nisâ min'el-Arab ve'lmüsta'rebîn ve'l-müsteșrikîn. Beyrut: Dârü'l-İlm li'l-Melayin, 1984. 